\title{
NR5A1 Gene
}

National Cancer Institute

\section{Source}

National Cancer Institute. NR5A1 Gene. NCI Thesaurus. Code C75870.

This gene plays a role in the regulation of transcription of steroid processing genes. 